iD https://orcid.org/0000-0001-5571-5175

Uniwersytet Jana Kochanowskiego w Kielcach

joanna.kowalczyk@ujk.edu.pl

\title{
WIELOWYMIAROWY OBRAZ ROSYJSKIEJ KONSTYTUCJI - REFLEKSJE JĘZYKOWE, KULTUROWE I POZNAWCZE
}

\section{Abstract}

A Multidimensional Image of the Russian Constitution - Linguistic, Cultural and Cognitive Reflections

This article deals with the transposition of concepts in the process of translating legal texts. The material basis was the original text of the constitution of the Russian Federation and the constitution of Russia, which was translated into Polish. The primary assumption of the analyzes made is the thesis that the constitution is the foundation of the system, norms and principles. The Constitution also sets out the main directions of community development. As the superior document of a social and political nature, it confirms the most important national values and social beliefs. The awareness of the highest rank of this normative act should also be considered as an important factor in the process of translating the constitution into other languages. Depending on the context and depending on the structural and conceptual flexibility of the original text, the transposition of a generalized vision of the community world can be a complex task or a process that does not require a lot of work.

The subject of the article is the relation between the Constitution of the Russian Federation and its Polish language version. The analysis includes the linguistic and non-linguistic reality in which the constitution of Russia is present. The research covered: the current constitution of Russia of December 12, 1993 in the Russian and Polish language versions. The legal act in Polish was made available on the official website of the Biblioteka Sejmowa (biblioteka.sejm.gov.pl). The aim of the review was to identify the possibility of reconceptualizing the Russian legal reality and determining the efficiency of transposing the concepts to the target text. The author wanted to answer the question 
whether the translation text can be treated as a source of knowledge and understanding of cultural and civilizational norms and values, building the state and Russian society. The first part of the study was devoted to general concepts that created the state system. Attention is paid to their functionality in the source and target area. The essence of the image of the world was taken into account. Using the concepts of Родина and Отечество, has been explained the lexical context of translated lexemes. The second part of the review concerned the reconstruction of the collective memory of the Russian nation. This level focuses on the text of the preamble as a component containing generalized ideas of the political system. The third part was a substantive summary of all findings. This part of the article was based on a comparative study, covering the relation between the text of the constitution and the content and context.

Keywords: legal text, constitution of Russia, translation, context, collective memory

Słowa kluczowe: tekst prawny, konstytucja Rosji, tłumaczenie, kontekst, pamięć zbiorowa

\section{Wstęp}

Konstytucja to spisane idee funkcjonowania państwa i tworzącego je społeczeństwa. Ustawa zasadnicza stanowi w tym wymiarze fundament normotwórczy, ustanawiający prymarne założenia ustrojowe i kierunki rozwoju wspólnoty. Jest odzwierciedleniem najważniejszych wartości narodowych, konceptów kulturowych, poglądów politycznych i przekonań społecznych. Zachowanie esencjonalności nadrzędnej, tj. odtworzenie głównych idei formułujących treść tego aktu normatywnego, staje się również czynnikiem przewodnim w procesie przekładu ustawy zasadniczej na inne języki. Dostrzeżenie w treści oryginału uogólnionego obrazu świata wspólnoty, która ten obraz zbudowała, pozwala na (przynajmniej częściowe) odtworzenie podmiotowej i przedmiotowej rzeczywistości podlegającej deskrypcji. To z kolei umożliwia przybliżenie systemowych norm i uzualnych zasad determinujących zachowanie, działania i stanowiska światopoglądowe członków społeczeństwa, do których odnosi się treść konstytucji.

Przedmiotem artykułu uczyniłam wybrane aspekty tłumaczenia na język polski tekstu obecnie obowiązującej konstytucji Federacji Rosyjskiej (Konstytucja Federacji Rosyjskiej z 12 grudnia 1993 roku). Szczególna uwaga została zwrócona na semantyczne odtworzenie podstawowych konceptów ustrojowych i społecznych (m. in. народ [lud/naród], Родина [ојсzyzna], Отечество [ojczyzna]), ich osadzenie w kontekście oraz relewancję 
funkcjonalną i językową przekładu względem oryginału. Analizę porównawczą przeprowadzono w celu określenia językowej specyfiki rosyjskokulturowej wizji świata w polskojęzycznym przekładzie. Ogląd komparatywny objął również kwestie barier językowych (np. brak bezpośredniego ekwiwalentu) i kulturowych (np. brak desygnatu).

Tekst Konstytucji Federacji Rosyjskiej (2000) w polskiej wersji językowej pochodzi z Biblioteki Sejmowej ${ }^{1}$, udostępniającej swe zbiory na stronie internetowej www.biblioteka.sejm.pl/konstytucje-swiata-rosja/. Tłumaczenia aktu normatywnego dokonał Andrzej Kubik ${ }^{2}$.

Celem artykułu jest próba przybliżenia relacji między konstytucją $\mathrm{Fe}$ deracji Rosyjskiej a jej polskojęzycznym odpowiednikiem w kontekście szeroko rozumianego konceptualizowania rzeczywistości prawnej, społecznej i aksjologicznej, który został wykreowany w tekście oryginalnym i jest odtwarzany w tekście docelowym. Punktem wyjścia jest twierdzenie, że konstytucja Rosji w wersji tłumaczonej na język polski może stanowić źródło poznania oraz zrozumienia kulturowo-cywilizacyjnych norm i wartości budujących państwo i społeczeństwo rosyjskie. Na tej kanwie opisano wybrane, językowe reprezentacje podobieństw tworzenia tekstów prawnych w obu językach (np. jednostka językowa должен/не должен [powinien / nie powinien] w prawnym znaczeniu musi / nie może), problemu wielości ekwiwalentów bliskoznacznych w języku docelowym (np. защита vs. ochrona, osłona, obrona), problemu niewystarczalności znaczeniowej polskojęzycznych ekwiwalentów (np. родина, отечество vs. ојсzуzna) oraz problemu specyficznej terminologii ustawodawczej języka źródłowego (np. добровольное согласие [dobrowolna zgoda]).

Głównymi założeniami metodologicznymi podjętej analizy stały się kryteria zwrotnej relewancji funkcjonalnej (tekst źródłowy vs. tekst docelowy; tekst docelowy vs. tekst źródłowy). To oznacza, że w badaniu skorzystano z podwójnej perspektywy: od oryginału do przekładu i od przekładu do oryginału. Ponadto uwzględnienie kontekstu powstawania i bytowania tekstu oryginału pozwoliło określić, czy treść konstytucji rosyjskiej w wersji translacyjnej jest adekwatną i skuteczną próbą odtworzenia lub/i przetransponowania obrazu rzeczywistości obcej.

1 Wybrano tę wersję tłumaczenia ze względu na jej oficjalną afirmację w Polsce.

2 Polskojęzyczne fragmenty Konstytucji Rosji, które pojawiły się w niniejszym artykule, zostały przetłumaczone przez Andrzeja Kubika, chyba że wskazano w tekście inne źródło. 


\section{Konstytucja Rosji jako amalgamat konceptów i quasi- -konceptów ustrojowych, ideowych oraz kulturowych}

Ustawa zasadnicza, to jest konstytucja co do zasady obejmuje swym zasięgiem uogólnione koncepty formujące system państwowy. Jednym z głównych przymiotów, będącym differentia specifica gatunku, jest ustabilizowanie wewnętrznych reguł funkcjonowania odgórnie zorganizowanej wspólnoty. W ten sposób konstytucja umożliwia (przynajmniej w pewnym stopniu) uniknięcie tymczasowości przyjętych założeń.

Oprócz pierwszorzędnego celu użytkowego - jakim jest ustanowienie i zachowanie porządku prawnego (por. Kowalczyk 2017: 113-118) - ustawa zasadnicza wyznacza, afirmuje i propaguje określone modele ustrojowe, ideowe i kulturowe. Ze względu na charakter niniejszego opracowania uwaga zostanie skupiona na dwóch ostatnich obszarach kognitywnych wpisanych w założenia konstytucji Rosji.

Obecnie obowiązujący w Rosji akt konstytucyjny jest z jednej strony wynikiem postradzieckiej myśli politycznej, z drugiej zaś - odzwierciedleniem wielowiekowych przyzwyczajeń do budowania społeczeństwa na fundamencie „ducha narodu” (por.: Kowalski 2009; Bosiacki, Izdebski 2013; Żbikowski 2017 i in.). Ze względu na charakter gatunkowy tego typu tekstów również konstytucja RF w wymiarze całościowym ma synkretyczną strukturę treściową.

Pierwsza płaszczyzna dotyczy różnorodnych poziomów ideowych i sfer kulturowo-społecznych, połączonych w odrębne, powszechne kategorie pojęciowe, np. prawa, obowiązki, nakazy, zakazy, por.:

- prawo do / prawo na

- Każdy ma prawo określić i zadeklarować swą przynależność narodową

[Каждый вправе определять и указывать свою национальную принадлежность (art. 26 ust. 1 KFR)];

- Każdy ma prawo do posługiwania się językiem ojczystym, do nieskrępowanego wyboru języka komunikowania się (...)

[Каждый имеет право на пользование родным языком, на свободный выбор языка общения (...) (art. 26 ust. 2 KFR)].

- obowiązek

- Obrona Ojczyzny jest powinnością i obowiązkiem obywatela Federacji Rosyjskiej 
[Защита Отечества является долгом и обязанностью гражданина Российской Федерации (art. 59 ust. 1 KFR)];

- Dzieci zdolne do pracy, które ukończyły 18 rok życia, winny otaczać opieką rodziców niezdolnych do pracy

[Трудоспособные дети, достигшие 18 лет, должны заботиться о нетрудоспособных родителях (art. 38 ust. 3 KFR)].

Najważniejszą cechą dystynktywną jest w tym wypadku ogólnikowość konceptualna, przekładająca się na schematy myślowe, będące tu rozszerzeniem rozumienia tekstu, np.: (wersja oryginalna) Никто не должен [nie powinien] подвергаться пыткам... vs. (wersja polskojęzyczna) Nikt nie może być poddany torturom... (art. 21 ust. $1 \mathrm{KFR}$ ).

Z kolei druga płaszczyzna wiąże się z quasi-konceptami prawnymi, których wartość faktyczną należy określić jako relatywną. Wyjaśniając znaczenie quasi-konceptu, można posłużyć się metaforą symulakrów, tj. zjawisk pozorowanych (por.: Baudrillard 1997). W kontekście założeń konstytucji rosyjskiej dotyczy to wyobrażonych, ale nierealizowanych (lub wybiórczo realizowanych) założeń ustrojowych, takich jak: wolność słowa, swoboda zgromadzeń, demokratyczne struktury państwa, pluralizm polityczny i in., por.:

- Federacja Rosyjska - Rosja jest demokratycznym federacyjnym państwem prawa o republikańskiej formie rządów (...)

[Российская Федерация - Россия есть демократическое федеративное правовое государство с республиканской формой правления (...) (art. 1 ust. 1 KFR)];

- W Federacji Rosyjskiej prawa i wolności czlowieka i obywatela uznaje się $i$ gwarantuje (...)

[В Российской Федерации признаются и гарантируются права и свободы человека и гражданина (...) (art. 17 ust. 1 KFR)];

- Wszyscy są równi w obliczu prawa i sądu

[Все равны перед законом и судом (art. 19 ust. 1 KFR)].

Odbiorca, który chciałby czerpać wiedzę o stanie społeczno-politycznym Federacji Rosyjskiej z konstytucji (również z jej wersji tłumaczeniowej); wkracza na płaszczyznę niejednoznacznych relacji między założeniami wdrożonymi a zasadami pozorowanymi. Dla odbiorcy znającego sytuację polityczną w Rosji dychotomia między rzeczywistością realną a rzeczywistością kreowaną w przestrzeni ustawy zasadniczej i innych aktów normatywnych może stać się determinantem, budującym dwupoziomową percepcję treści. Z jednej strony skupi się on na przyswajaniu pojęć, konceptów, idei przybliżających faktyczne wartości kształtujące obraz świata członków 
wspólnoty rosyjskiej, z drugiej - na odczytaniu lub pominięciu poznawczo „pustego" (pozostającego w sferze postulowanych idei) tekstu, por.:

- Czlowiek, jego prawa i wolności są wartością najwyższą. Uznawanie, przestrzeganie i obrona praw i wolności człowieka i obywatela jest powinnościa państwa

[Человек, его права и свободы являются высшей ценностью.

Признание, соблюдение и защита прав и свобод человека и гражданина - обязанность государства (art. 2 KFR)]. vs.

Prezydent Rosji Władimir Putin podpisał (...) ustawę, która daje Sądowi Konstytucyjnemu prawo do decydowania o tym, czy respektować lub odrzucać orzeczenia międzynarodowych organów ds. praw czlowieka (...) (fakty.interia.pl: 2015);

17 ofiar śmiertelnych, brak wynagrodzeń dla pracowników, a do tego skandaliczne warunki pracy (...) (sportowefakty.wp.pl: 2017).

\section{Językowy obraz świata w perspektywie translacji tekstów ogólnospołecznych}

Wyodrębnienie z hiperrzeczywistości konstytucyjnej obrazów językowych (zwerbalizowanych przekonań, wartości, zasad, idei) dających możliwość poznania kultury obcej nie jest procesem intuicyjnym. Efektywność zastosowanych metod przekładu, co dotyczy procesu translacji w ogóle, opiera się bowiem na świadomym działaniu tłumacza, który etapowo buduje odbicie

informacji sformułowanych w języku fachowym dla określonego typu odbiorcy i służących ściśle wytyczonym celom. Zatem od tłumacza tego rodzaju tekstów będzie wymagać się umiejętności rozpoznania intencji autora tekstu, czyli dogłębnego zrozumienia treści i celu jego przekazu, określenia grupy odbiorców oraz przede wszystkim oddania sensu oryginału w języku docelowym (Kopczyńska 2015: 114-115).

W wypadku tekstów prawnych zachowanie wartości oryginału wiąże się przede wszystkim z przekazaniem adekwatnej i pełnej informacji. Czynnik precyzji informacyjnej jest pragmatycznie nieodłącznym i prymarnym komponentem procesu translacji. Zastosowanie relewantnych narzędzi językowych wymaga nie tylko posiadania kompetencji lingwistycznych, ale także wiedzy kulturowo-cywilizacyjnej o obu obszarach, w których tekst 
normatywny funkcjonuje i będzie funkcjonował. Na wskaźnik dokładności oraz bliskości teksu źródłowego i docelowego oddziałują bowiem również fakty pozajęzykowe.

Percepcja u każdego odbiorcy ma charakter synestezji i na odbiór tekstu jednocześnie nakładają się jego: obraz świata, językowy obraz świata, zasób wiedzy i horyzont doświadczenia. Podstawowym determinantem pracy tłumacza w tym wymiarze staje się więc opisanie świata źródłowego w terminach języka docelowego. Nie zawsze jednak jest to proces bezproblemowy, zwłaszcza gdy w obu systemach semiotycznych pojawiają się elementy do siebie nieprzystające. Przykładami niekompatybilności przestrzeni językowej i kognitywnej między rosyjską i polską reprezentacją rzeczywistości są koncepty: Родина і Отечество, por.:

(...) w poczuciu odpowiedzialności za Ojczyznę wobec obecnego i przyszłych pokoleń $(\ldots)$

$[(\ldots)$ исходя из ответственности за свою Родину перед нынешним и будущими поколениями (...) (Preambuła KFR)];

czcząc pamięć przodków, po których odziedziczyliśmy miłość i szacunek do Ojczyzny

$[(. .$.$) чтя память предков, передавших нам любовь и уважение к Отечеству$ (...) (Preambuła KFR)].

W polskiej wersji tłumaczeniowej do wyjaśnienia obu pojęć został zastosowany najbliższy dostępny (i adekwatny stylistycznie) ekwiwalent konceptualny, tj. ojczyzna. Warto jednak wyjaśnić, że w języku rosyjskim to, co użytkownicy języka polskiego nazywają ojczyzna, zostało podzielone na dwa zbliżone, ale nie tożsame koncepty, tj. Родина і Отечество. Pole semantyczne pojęcia Родина obejmuje m.in. idee kraju rodzinnego; kraju dzieciństwa; ukochanego miejsca; miłości do ojczyzny; przywiązania do wspólnoty. Ma to swoje odzwierciedlenie w powiedzeniach i przysłowiach:

- Родина - мать, умей за неё постоять [Ojczyzna - matka, umiej ją ochronić - tłum. własne];

- Человек без Родины, что соловей без песни [Człowiek bez Ojczyzny jak słowik bez śpiewu - tłum. własne];

- Любовь к Родине сильнее смерти [Miłość do Ojczyzny silniejsza niż śmierć - tłum. własne]. 
Z kolei pole konotacji pojęcia Отечество odnosi się m.in. do kraju pochodzenia; kraju przodków; kraju zamieszkania; szacunku do ojczyzny, jak w następujących przysłowiach, cytatach i powiedzeniach:

- К Ко Отечество предает, тот нечистой силе свою душу продает [Kto Ojczyznę zdradza, ten nieczystej sile duszę zaprzedaje - tłum. własne];

- Кто с пользой для Отечества трудится, тот с ним легко не разлучится (Крылов: 1945-1946) [Kto dla dobra Ojczyzny pracuje, ten się z nią łatwo nie rozstanie - tłum. własne].

Jak zostało wskazane, Родина і Отечество na gruncie dyskursu rosyjskiego przywołują inne skojarzenia. Родина jest konceptem o podłożu emocjonalnym, nostalgicznym, duchowym. Natomiast Отечество posiada mocniej zarysowaną racjonalizację relacji państwo-obywatel. Łączy się z takimi pojęciami jak: przynależność etniczna, polityka, ustrój.

W wypadku tłumaczenia konceptów Родина і Отечество na język polski w tekstach sformalizowanych nie jest możliwa pełna transpozycja idei rozdzielania obu wyobrażeń. $Z$ tego powodu odbiorca przekładu polskojęzycznego otrzymuje wypośrodkowany efekt próby zespolenia wizji źródłowej z zasobem pojęć i narzędzi językowych, którymi dysponują członkowie wspólnoty polskojęzycznej.

\section{Preambuła konstytucji jako źródło pamięci zbiorowej}

Przyjmując, że pamiętanie zbiorowe (skorelowane międzyludzko) ma cechy rzeczywistego faktu społecznego, należy uznać, że percepcja każdego członka społeczności stanowi częściowe odwzorowanie wspólnego doświadczenia abstrakcyjnego - tożsamości (narodowej, etnicznej, kulturowej itd.).

W takim wymiarze i z takiej perspektywy pamięć zbiorowa

przestaje być intelektualną fikcją. Jest dynamicznym procesem identyfikacji z selektywnie wybranymi fenomenami historycznymi. Proces ten za pomocą zdarzeń społecznych, takich jak: polityczne rytuały (...), rozgrywa się w naszych głowach i zarazem w przestrzeni publicznej. Uczestnicząc w publicznych działaniach kreujących obrazy przeszłości w przestrzeni publicznej, stajemy się nolens volens aktorami procesu konstruowania pamięci zbiorowej (Traba 2014: 114). 
Jednym z immanentnych komponentów pamięci zbiorowej jest jej przeciwległy biegun - zapominanie, ponieważ pamięć zbiorowa to proces zapamiętywania i zapominania (Czarnota 2013: 204), realnie oddziałujący na postrzeganie, zachowanie, interpretację i działania osób włączonych w przestrzeń jej wpływu. Jako wytwór relacji asocjacyjnych (por. Szałek 2004) znajduje zastosowanie w tekstach kulturowo znaczących - również prawnych.

\subsection{Rekonceptualizacja determinantów prymarnych}

W ramach dyskursu oficjalno-prawnego konstytucja jest jednym $\mathrm{z}$ fundamentów pamięci zbiorowej, a w szczególności jej część wstępna - preambuła, zawierająca nie polityczne, lecz społeczne idee, obrazujące horyzont doświadczenia wspólnoty. W wypadku konstytucji Rosji to właśnie ta część aktu normatywnego daje najpełniejszą informację czytelnikowi polskojęzycznemu o kulturze, historii i fundamentach światopoglądowych wspólnoty rosyjskiej. Ze względu na systemową bliskość języka polskiego i rosyjskiego przekład dał precyzyjne odbicie oryginału. W celu zilustrowania poziomów przekazu (w obu wersjach językowych) z preambuły wyekscerpowano, a następnie opisano najważniejsze elementy treściowe, umożliwiające przybliżenie kulturowo-cywilizacyjnych aspektów kształtujących społeczeństwo rosyjskie:

My, wielonarodowy lud federacji Rosyjskiej, złączeni wspólnym losem (...)

[Мы, многонациональный народ Российской Федерации, соединенные общей судьбой (...)].

Zaznaczenie niejednorodności społeczeństwa rosyjskiego przekazuje odbiorcy polskojęzycznemu jednoznaczną informację o złożonej strukturze etnicznej Rosji, natomiast zastosowanie zaimka „My” oraz zwrócenie uwagi na „wspólny los” buduje obraz wspólnoty różnorodnej, ale połączonej historycznie i mentalnie.

W kolejnym przywołanym fragmencie zauważalna jest kontynuacja myśli przewodniej, czyli zespolenia różnorodnych grup etnicznych i narodowych w jednym systemie odgórnie zorganizowanym - w państwie. Dodatkowym elementem konstytuującym wartość połączenia wielu wspólnot w całość jest jego historyczne utrwalenie: 
(...) zachowując historycznie uksztaltowaną wspólnotę państwową (...)

$[(\ldots)$ сохраняя исторически сложившееся государственное единство $(\ldots)]$.

Następna cząstka tekstu preambuły również odnosi się do wielonarodowości społeczeństwa rosyjskiego, ale dotyczy identyfikacji rodowo-kulturowej. Treść założeń omawianego aktu normatywnego akcentuje szacunek do indywidualnych tradycji odrębnych grup ludności:

(...) kierując się ogólnie uznanymi zasadami równouprawnienia i samookreślenia narodów (...)

$[(\ldots)$ исходя из общепризнанных принципов равноправия и самоопределения народов (...)].

W dalszej części ustawodawca odwołał się do wartości, jaką jest nieprzerwane przekazywanie idei patriotycznych. W ten sposób ugruntował wielopokoleniowe postrzeganie ojczyzny jako obiektu troski i szacunku:

czcząc pamięć przodków, po których odziedziczyliśmy miłość i szacunek do Ojezyzny

[чтя память предков, передавших нам любовь и уважение к Отечеству].

Warto dodać, że wersja tłumaczeniowa nie oddaje jednego z poziomów treści. Nie uwydatnia faktu (zaznaczonego w tekście oryginału), że szacunek do Rosji nie jest emocją daną (por. „odziedziczyliśmy miłość i szacunek”), lecz przekazywaną z pokolenia na pokolenie wartością narodową (por. „чтя память предков, передавших нам любовь и уважение к Отечеству” [czcząc pamięć przodków, którzy przekazali nam miłość i szacunek do Ojczyzny - tłum. własne]).

Z dalszej części polski odbiorca może uzyskać informacje o najważniejszych celach powołania aktu konstytucyjnego. Została podkreślona myśl przewodnia, czyli odpowiedzialność za zjednoczoną wspólnotę w obecnej i przyszłej postaci:

(...) w poczuciu odpowiedzialności za Ojczyznę wobec obecnego i przyszlych pokoleń (...);

$[(\ldots)$ исходя из ответственности за свою Родину перед нынешним и будущими поколениями (...)]. 
Fragment kończący tekst preambuły umożliwia zwrócenie uwagi na jedną z głównych cech mentalności społeczeństwa rosyjskiego. Niezależnie od sytuacji politycznej, gospodarczej i społecznej, Rosja jako państwo ujawnia silne aspiracje do bycia liczącym się partnerem na arenie międzynarodowej:

(...) uważając się za część społeczności światowej (...);

$[(\ldots)$ сознавая себя частью мирового сообщества $(\ldots)]$.

Predylekcje do nieustannego kreowania wizerunku światowego mocarstwa przeradzają się również w realne ambicje imperialistyczne. Rzeczywistym i jednocześnie symbolicznym efektem działań powiększania strefy wpływów stała się aneksja Krymu w 2014 roku i konstytucyjna afirmacja jego wcielenia do Federacji Rosyjskiej:

W skład Federacji Rosyjskiej wchodzą podmioty Federacji Rosyjskiej: (...) Republika Krym (...) (art. 65 KFR-ARwP);

[B составе Российской Федерации находятся субъекты Российской Федерации: (...) Республика Крым (...)].

Warto wspomnieć, że polskojęzyczny tekst konstytucji Rosji umieszczony na stronie internetowej Biblioteki Sejmowej nie został zaktualizowany. Tłumaczenia nie uzupełniono o zmiany w ustroju federalnym (być może jest to zabieg celowy). Tekst znowelizowany, uwzględniający „Republikę Krym” jako część Rosji, w wersji tłumaczonej na język polski dostępny jest m.in. na stronie internetowej ambasady Rosji w Polsce.

Dotychczasowe ustalenia dały wgląd w ustrojowe i pozaustrojowe determinanty formowania tekstu konstytucji rosyjskiej w wersji oryginalnej i thumaczeniowej. Wielowiekowe tradycje oraz doświadczenia historyczne również aktualnie mają realny wpływ na światopogląd członków wspólnoty rosyjskiej, ich postrzeganie rzeczywistości i innych kultur. Obraz świata kształtuje się bowiem poprzez bezrefleksyjne przyswajanie, refleksyjne oceny i wielokrotnie odtwarzane zachowania. Dlatego też w tekście preambuły, napisanym w czasach przełomów politycznych (rozpad ZSRR), nadal ma swe odbicie uogólniona rosyjska tożsamość zbiorowa. 


\section{Skuteczna transpozycja obrazu świata a warunki rzeczywistości obcej}

Biorąc pod uwagę fakt, że konstytucja Rosji to akt symboliczny - wskazujący postulowane idee - odróżnienie opisywanej w niej rzeczywistości faktycznej od rzeczywistości tekstowej nie jest procesem intuicyjnym. Aby móc nawet w stopniu przybliżonym odtworzyć obraz świata społeczeństwa rosyjskiego, niezbędna wydaje się znajomość złożonej sytuacji politycznej i społecznej panującej w Federacji Rosyjskiej. Bez horyzontu interpretacji oraz bez punktu odniesienia uchwycenie treści oryginalnych przepisów konstytucyjnych staje się trudne do zrealizowania.

Podejmując próbę określenia elementów determinujących pracę tłumacza oraz percepcję tekstu przekładu, wyodrębniono dwie podstawowe płaszczyzny: językowo-konceptualną i polityczno-rzeczywistą. Pierwsza kategoria dotyczyła skuteczności transpozycji terminów. Kategoria druga obejmowała ocenę przystawania tekstu konstytucji do realiów źródłowych.

Wśród przykładów tłumaczeń klasy językowo-konceptualnej znalazły się omówione koncepty Родина і Отечество, ale także leksemy, takie jak: государственный [państwowy/publiczny], защита [obrona/ochrona], личность [osoba/jednostka], режим [procedury/zasady] i inne. W tabeli 1 umieszczono przykłady ilustrujące specyfikę funkcjonowania wybranych terminów w warunkach tekstu źródłowego i sposób ich wdrażania do tekstu tłumaczenia.

Tabela 1. Specyfika transpozycji językowo-formalnej

\begin{tabular}{|c|c|c|}
\hline $\begin{array}{l}\text { Tekst } \\
\text { przekładu }\end{array}$ & $\begin{array}{l}\text { Tekst } \\
\text { oryginalny }\end{array}$ & Przykłady użycia \\
\hline $\begin{array}{l}\text { porzadek } \\
\text { spoteczny }\end{array}$ & $\begin{array}{l}\text { общественный } \\
\text { порядок }\end{array}$ & $\begin{array}{l}\text { (pol.) Rząd Federacji Rosyjskiej (...) chroni własność } \\
\text { i porządek społeczny (...); } \\
\text { (ros.) Правительство Российской Федерации (...) } \\
\text { осуществляет меры по (...) охране собствен- } \\
\text { ности и общественного порядка (...) (art. } 114 \\
\text { ust. } 1 \text { KFR); }\end{array}$ \\
\hline $\begin{array}{l}\text { porządek } \\
\text { publiczny }\end{array}$ & $\begin{array}{l}\text { обществвенный } \\
\text { порядок }\end{array}$ & $\begin{array}{l}\text { (pol.) Organy samorządu lokalnego (...) strzegą } \\
\text { porządku publicznego }(. . .) \text {; } \\
\text { (ros.) Органы местного самоуправления (...) осу- } \\
\text { ществляют охрану общественного порядка }(. . .) \\
\text { (art. } 132 \text { ust. } 1 \text { KFR); }\end{array}$ \\
\hline
\end{tabular}




\begin{tabular}{|c|c|c|}
\hline obrona & защита & $\begin{array}{l}\text { (pol.) Uznawanie, przestrzeganie i obrona praw } \\
\text { i wolności człowieka i obywatela jest powinnością } \\
\text { państwa; } \\
\text { (ros.) Признание, соблюдение и защита прав } \\
\text { и свобод человека и гражданина - обязанность } \\
\text { государства (art. } 2 \text { KFR); }\end{array}$ \\
\hline ochrona & защита & $\begin{array}{l}\text { (pol.) Każdy ma prawo do zrzeszania się (...) w celu } \\
\text { ochrony swoich interesów; } \\
\text { (ros.) Каждый имеет право на объединение (...) } \\
\text { для защиты своих интересов (art. } 30 \text { ust.1 KFR); }\end{array}$ \\
\hline osłona & защитта & $\begin{array}{l}\text { (pol.) (...) wprowadza się państwowe świadczenia } \\
\text { emerytalne, zasiłki oraz inne gwarancje osłony } \\
\text { socjalnej; } \\
\text { (ros.) (...) устанавливаются государственные } \\
\text { пенсии, пособия и иные гарантии социальной } \\
\text { защиты (art. } 7 \text { ust. } 2 \text { KFR). }\end{array}$ \\
\hline
\end{tabular}

Źródło: opracowanie własne.

W tabeli umieszczono egzemplifikacje dotyczące leksykalnej i semantycznej odrębności obu języków. Odmienność ta w procesie poszukiwania ekwiwalentów terminologicznych wymagała analizy pragmatycznej tekstu oryginalnego, a następnie dopasowania polskich odpowiedników zgodnych ze standardami języka prawnego. Prowadząc analizę, zwrócono uwagę na rozbieżności w zakresie funkcjonalnym pewnych terminów. Dobór ekwiwalentu w tym wypadku albo przybliżał i oswajał tekst źródłowy, albo wprowadzał elementy kalkowane. Domestykacja terminów obcych oddalała tekst źródłowy, ale przybliżała sens treściowy (np. zastosowanie w tekście polskojęzycznym używanego w polskim dyskursie polityczno-prawnym frazemu porządek publiczny zamiast kalki porzadek społeczny). Egzotyzacja tekstu docelowego wprowadzała natomiast niewielkie innowacje językowe, ale redukowała ingerencję w tekst źródłowy (np. zastosowanie w tekście polskojęzycznym skalkowanego frazemu samorząd lokalny zamiast rodzimego samorzad terytorialny). Z perspektywy odbiorcy korzystniejszym rozwiązaniem było stosowanie pojęć rodzimych dla oznaczenia konceptów nieznanych, nawet jeśli nie stanowiły pełnego odwzorowania pojęcia.

$\mathrm{Z}$ kolei kryterium polityczno-rzeczywiste $\mathrm{w}$ ramach przetłumaczonego aktu normatywnego dotyczyło wtórnej interpretacji tekstu przez odbiorcę. Ze względu na charakter przekładu (przekład specjalistyczny) ingerencja tłumacza w treść ograniczyła się do wyboru odpowiedniego ekwiwalentu 
pojęciowego i językowego. Z tego powodu w tej grupie umieszczono również elementy językowe nienaturalne dla odbiorcy docelowego (takie, które nie występują w kulturze odbiorcy), ale wprowadzane literalnie do tekstu polskojęzycznego jako wskazania elementów specyficznych dla przestrzeni źródłowej, np. добровольное согласие [dobrowolna zgoda]. W kontekście wspólnot demokratycznych zgoda zawsze jest dobrowolna, ponieważ stanowi wyznacznik aksjologii wolności (por. Ławrynowicz-Miklaszewicz 2014). Kryterium polityczno-rzeczywiste pozwoliło również ocenić faktyczny status konstytucji w Rosji. Z formalnego punktu widzenia ustawa zasadnicza stanowi niewzruszone źródło prawa:

Konstytucja Federacji Rosyjskiej i Ustawy Federalne mają najwyższą moc obowiązującą (...)

[Конституция Российской Федерации и федеральные законы имеют верховенство (art. 4 ust. 2 KFR)];

Konstytucja Federacji Rosyjskiej ma najwyższą samoistną moc prawną (...) [Конституция Российской Федерации имеет высшую юридическую силу, прямое действие (art. 15 ust. 1 KFR)].

W ramach studium komparatywnego konstytucyjne przepisy prawne skonfrontowano z rzeczywistością pozajęzykową. Uwzględniając czynniki pozatekstowe, można uznać konstytucję Federacji Rosyjskiej jedynie za utwór symboliczny, którego wpływ na sytuację polityczną, ustrojową i społeczną w Rosji jest ograniczony. Brak przełożenia treści na realia możliwy jest do dostrzeżenia jedynie przez odbiorcę będącego członkiem wspólnoty rosyjskiej, który zdaje sobie sprawę z wybiórczego respektowania postanowień konstytucyjnych, lub/i przez odbiorcę świadomego rozdźwięku między rzeczywistością sztucznie kreowaną a faktami społecznymi. Konstytucja wskazuje na przykład na pluralizm polityczny i wielopartyjność (art. 13 ust. $3 \mathrm{KFR}$ ), ale de facto to założenie nie jest respektowane:

Wybory w Rosji. Dopuszczono 14 partii, ale to tylko gra pozorów (polskieradio.pl);

Wybory miały wyglądać na czyste. Nie wyszło. „Nawet Putin jest bezradny wobec systemu" (tvn24.pl).

Ustawa zasadnicza gwarantuje wolność myśli i słowa (art. 29 ust. 1 KFR), a w rzeczywistości jest to przepis martwy: 
Merkel apeluje o wolność słowa w Rosji. „Dla ludzi myślących inaczej” (dziennik.pl);

Według Press Freedom Index Rosja plasuje się na 148. miejscu na 179, jeśli chodzi o wolność słowa (cafebabel.pl).

Konstytucja głosi, że w środkach masowego przekazu zabrania się stosowania cenzury (art. 29 ust. 5 KFR), lecz realna sytuacja w państwie przeczy tym założeniom:

W Rosji rusza cenzura Internetu (wolnemedia.pl);

Prześladowania dziennikarzy, zamknięcie telewizji. Mocna cenzura na Krymie (forsal.pl).

Omówione przykłady charakteryzują relatywizm obowiązywania ustawy zasadniczej w Rosji. Już chociażby z tego powodu odbiorca tłumaczenia polskojęzycznego również zostaje postawiony przed niełatwym zadaniem odróżnienia tekstu dokumentu od treści właściwej. W takiej perspektywie wyodrębnienie z tekstu konstytucji informacji praktycznych przez odbiorcę nieświadomego sytuacji polityczno-społecznej w Rosji jest znacznie utrudnione. Nawet przed odbiorcą świadomym stoi niełatwe zadanie. Musi on dokonywać nieustannej selekcji zasad jedynie zapisanych (przepisów martwych) i tekstów performatywnych (przestrzeganych i regulujących rzeczywistość pozajęzykową).

\section{Zakończenie}

Dokonana na potrzeby niniejszego oglądu analiza stała się refleksją nie tylko przekładoznawczą, ale również społeczną, polityczną i aksjologiczną. Badanie tekstu konstytucji Rosji w języku oryginalnym oraz jej wersji polskojęzycznej dało uogólniony ogląd zarówno na problemy procesu tłumaczenia, jak i na rzeczywistą pragmatykę aktów normatywnych.

W trakcie analizy uwagę zwrócono przede wszystkim na rangę dokumentu, jakim jest konstytucja. Był to punkt wyjściowy badań. Już ogląd prima facie pozwolił wyodrębnić co najmniej kilka głównych płaszczyzn tekstowych i pozatekstowych, w których funkcjonuje ustawa zasadnicza Federacji Rosyjskiej. Rozpoczynając analizę, przyjęto, że badaniu zostanie poddany nadrzędny, powszechnie obowiązujący akt, jednak dalsza część 
badania wykazała, że faktyczna ranga konstytucji Rosji nie jest ustabilizowana. Najpoważniejszym problemem poznawczym okazała się względna funkcjonalność konstytucji, zaprzeczająca teorii korespondencyjności prawdy (zgodności tekstu ze stanem faktycznym). Ustawa zasadnicza formalnie posiada status aktu bezwzględnie prawodawczego i ustrojodawczego, lecz w odniesieniu do jej realnego przestrzegania (łamanie praw człowieka, ograniczanie wolności słowa, zablokowany pluralizm polityczny, falandyzacja prawa) przybiera postać utworu tekstowego, którego pragmatyka i użytkowość sytuują się na poziomie relatywnego obowiązywania.

Na podstawie powyższych refleksji wyekscerpowano i poddano właściwemu opisowi konkretne fragmenty tekstów polskojęzycznej i rosyjskojęzycznej konstytucji. Zwrócono uwagę na podobieństwa i różnice w sposobach opisywania rzeczywistości ustrojowej w obu językach. Podobieństwa łączyły się z intersubiektywnym modelem tworzenia tekstów prawnych. Różnice dotyczyły przede wszystkim kwestii nieprzystawalności konceptów tłumaczonych i pojęć używanych do ich opisu w języku docelowym (np. общественный порядок vs. porządek publiczny, porzadek społeczny).

Wykazano, że podczas tłumaczenia konstytucji możliwe było przetransponowanie poszczególnych, całościowych konceptów (np. мировое сообщество [społeczność światowa]). Możliwe było również przybliżone wskazanie fundamentów, na których została zbudowana oryginalna treść konstytucji (por. przekład preambuły). Za istotny fakt uznano również to, że odbiorca tekstu polskojęzycznego, w odniesieniu do terminów prawnych, otrzymywał informacje na dwóch poziomach użytkowości: bezpośrednim i pośrednim. Po pierwsze: zostały mu przedłożone tłumaczenia kalkowane, będące językowym odwzorowaniem rosyjskojęzycznego nazewnictwa (np. osoby pełniace funkcje państwowe zamiast osoby pełniące funkcje publiczne; Duma zamiast izba niższa parlamentu itp.). Po drugie: odczytywał przeniesione koncepty będące transpozycją pojęć. Przeniesienie to osadzało się m.in. na domestykacji - przybliżeniu odbiorcy innego systemu ustrojowego i społecznego poprzez użycie najbliższych funkcjonalnie rodzimych ekwiwalentów (np. Родина [ojczyzna], Отечество [ojczyzna]). 


\section{Bibliografia wraz z wykazem skrótów}

Konstytucja Federacji Rosyjskiej z dn. 12 grudnia 1993 r. 2000. przeł. A. Kubik. 2000. Warszawa: Wydawnictwo Sejmowe, w: Biblioteka Sejmowa, http://libr.sejm.gov.pl/ tek01/txt/konst/rosja.html (dostęp: 10.02.2020).

KFP-ARwP - Konstytucja Federacji Rosyjskiej z dn. 12 grudnia 1993 r., w: Ambasada Rosji w Polsce, https://poland.mid.ru/web/polska_pl/konstytucja-federacji-rosyjskiej (dostęp: 10.02.2020).

KFR - Конституция Российской Федерации, 12 декабря 1993 г., w: Constitution.ru, http://www.constitution.ru/ (10.02.2020).

Крылов И.А. 1945-1946. Пчела и мухи, w: Полное собрание сочинений, t. 3, Москва:

Государственное издательство художественной литературы, s. 136-137.

Baudrillard J. 1997. Precesja symulakrów, przeł. T. Komendant, w: R. Nycz (red.), Postmodernizm. Antologia przekładów, Kraków: Wydawnictwo Baran i Suszczyński, s. 175-189.

Bosiacki A., Izdebski H. 2013. Konstytucjonalizm rosyjski: historia i współczesność, Kraków: Arcana.

Czarnota A. 2013. Prawo, historia a pamięć zbiorowa. Przyczynek do związków między historia a socjologia prawa, „Miscellanea Historico-iuridica”, t. 12, s. 203-216. Kopczyńska M. 2015. Przekład tekstów specjalistycznych-oczekiwania $i$ wyzwania a praktyka, ,Rocznik Przekładoznawczy. Studia nad Teorią, Praktyką i Dydaktyką Przekładu" 10, s. 113-126.

Kowalczyk J. 2017. Pragmatyka komunikacji urząd-obywatel, Kraków: Libron.

Kowalski J. 2009. Konstytucja Federacji Rosyjskiej a rosyjska i europejska tradycja konstytucyjna, Warszawa-Poznań: Polskie Wydawnictwo Prawnicze.

Ławrynowicz-Maklaszewicz M. 2014. Aksjologia wolności, „Przegląd Prawniczy, Ekonomiczny i Społeczny" 3, s. 100-115.

Szałek P. 2004. Pamięć jako akt intencjonalny (trzy teorie psychologiczne), „Przegląd Filozoficzny - Nowa Seria" R. 13, nr 1(49), s. 25-38.

Traba R. 2014. Dialogi pamięci. Rozważania wokót recepcji pamięci zbiorowej, „Sensus Historiae" 2, 113-125.

Żbikowski W. 2017. O Konstytucji Federacji Rosyjskiej: wybrane zagadnienia, „Zeszyty Naukowe Prawa Konstytucyjnego" 10, 177-190.

http://fakty.interia.pl/swiat/news-putin-podpisal-ustawe-to-lamanie-praw-czlowieka, nId,1938974 (dostęp: 17.012018).

http://forsal.pl/artykuly/863128,przesladowania-dziennikarzy-zamkniecie-telewizji-mocna-cenzura-na-krymie.html (dostęp: 22.01.2018).

http:/wiadomosci.dziennik.pl/swiat/artykuly/484338,zabojstwo-borysa-niemcowamerkel-bedzie-walczyc-o-wolnosc-slowa-w-rosji.html (dostęp: 22.01.2018).

http://www.cafebabel.pl/polityka/artykul/caa-prawda-o-dziennikarstwie-w-rosji.html (dostęp: 21.01.2018).

https://sportowefakty.wp.pl/pilka-nozna/693571/ms-2018-rosjanie-oskarzeni-o-lamaniepraw-czlowieka-17-osob-zmarlo-przy-budowie- (dostęp: 17.01.2018). 
https://wolnemedia.net/w-rosji-rusza-cenzura-internetu/ (dostęp: 22.01.2018).

https://www.polskieradio.pl/5/3/Artykul/1668953, Wybory-w-Rosji-Dopuszczono14-partii-ale-to-gra-pozorow (dostęp: 20.01.2018).

https://www.tvn24.pl/wiadomosci-ze-swiata,2/wybory-w-rosji-nagrania-pokazuja-falszerstwa-wyborcze,677303.html (dostęp: 20.012018). 